\title{
The Choice of Place and Product Availability to Retail Business Continuity
}

\author{
Andrian Andrian ${ }^{1}$, Supardi Supardi ${ }^{2}$
}

1,2Universitas Bhayangkara Jakarta Raya, email : andriantahar@gmail.com

\section{ARTICLES \\ INFORMATION}

ABSTRACT

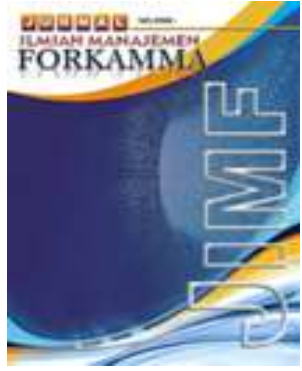

\section{JURNAL ILMIAH MANAJEMEN FORKAMMA}

Vol.4, No.2, Maret 2021

Halaman : $162-175$

C LPPM \& FORKAMMA

Prodi Magister Manajemen

UNVERSITAS PAMULANG

ISSN (online) : 2599-171X

ISSN (print) : :2598-9545

\section{Keyword :}

descriptive; quantitative; significant; struggle; uniqueness.

JEL. classification :

M31

\section{Contact Author :}

PRODI

\section{MAGISTER MANAJEMEN \&} FORKAMMA UNPAM

JL.Surya Kencana No.1 Pamulang

Tangerang Selatan - Banten

Telp. (021) 7412566, Fax (021) 7412491

Email :

jurnalforkamma.unpam@gmail.com
The research aims to know whether retail business can struggle against the situation nowadays. Ones of the most important factors when running a business are location and product availability. One of the largest franchise networks in Indonesia is PT. Lion Super Indo (Superindo Stores). The research was conducted in two Superindo stores located in Bekasi Timur Sub-district by giving questionnaires to 200 respondents/consumers. The descriptive quantitative and multiple linear regression analysis research methods were used. The results of this study are that Choice of Place variable has a negative and no significant effect on Business Continuity while Product Availability variable has a positive and significant effect on Business Continuity. The uniqueness of this study is that Business Continuity variable can be affected by Product Availability variable of $4.7 \%$ of the other factors. 


\section{JURNAL

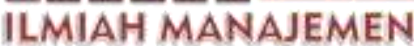 \\ ISSN (print) : 2598-9545 \& ISSN (online) : 2599-171X \\ FORKAMMA}

\section{A. INTRODUCTION}

The part of the economy which is one of the most important parts is the existence of an intermediary in the marketing channel, is a retailer (retailing) as the last supplier to consumers. According to some understanding retail experts is as follows :

Definition of retailing according to (Philip Kotler, 2012) "Retailing includes all the activities involved in selling goods or service directly to final consumer for their personal non business use ". That is, retail includes all the activities involved in the sale of goods or services directly to end consumers for Their non-business personal use is the same as a retail sense (retailing) according to Berman and Evans (Berman, B., and Evans, 2010) "Retailing encompasses the business activities involved in selling goods and service to consumers for their personal, family, or household use ". In other words, retail includes all business activities involving the sale of goods and services to consumers for their personal, family, or household needs. Meanwhile, according to Weitz (Weitz, 2019), Retail Mix is a collection of discussions that retailers have in order to meet the needs of their customers and influence their purchasing decisions. Elements of the retail mix include promotional program types, store design, merchandise displays, salesperson assistance to customers, and the convenience of the store's location. Retail Mix is a set of decisions made by retailers to meet needs buyers and influence purchasing decisions. An element in the retail mix including promotional programs, store design, goods display, support for buyers by the salesperson, and the convenience of the store location.

Retail can be interpreted from the origin of the word which comes from French, "ritellier", which means to cut or break something. Activity related that is carried out, then retail shows an effort to break down the goods or products produced and distributed by manufacturers or companies in quantities large and bulk to be consumed by end consumers in small quantities according to their needs according to Utami (Utami, 2012).

Along with the development of the retail business, at this time, the retail business is no longer managed traditionally, but in a modern way. Intense competition in the retail business cannot be separated from the proliferation of shopping centers either local, national, or international with a variety of factors targeted. The competition has spurred business people in retail sector to always become the consumers of retailers choice and keep their consumers.

Minimarket is a type of retail businesses that is growing rapidly today that sells daily necessities, offering convenience because of its accessible location and close to consumers, and that prioritizes practicality and speed supported from the area of stores or outlets that is not too large, so that consumers shop with not too long time. Another advantage of shopping at the convenience store is safe and comfortable atmosphere of shopping, no difficulty in choosing the items needed, more guaranteed quality of goods when compared to the traditional markets, and fixed price of products, so that negotiation is not needed and consumers can shop for various purposes in one place, thus saving time and effort. Besides, the availability of products sold in these retail stores still maintains trust and comfort of the customers to keep these customers shopping at the stores.

Super Indo has grown and developed with the Indonesian people since 1997, thanks to a collaboration between the Salim Group in Indonesia and Ahold Delhaize in the Netherlands.

Super Indo now has 186 stores spread across 40 cities on the Indonesian island of Java and the southern part of Sumatra. Super Indo, with over 8,500 trained employees, offers a wide range of daily necessities with dependable and complete quality, low prices, and convenient store locations.

Freshness and product quality are always maintained through a good selection of sources and handled with standard operating procedures that are always monitored. This makes Super Indo the choice for shopping place that is always "Fresher", "More Efficient", and "Closer".

JIMF (Jurnal IImiah Manajemen Forkamma), Vol.4, No.2, Maret 2021 


\section{песа \\ IUMAA MANAEEEN \\ ISSN (print) : 2598-9545 \& ISSN (online) : 2599-171X \\ FORKAMMA}

In providing fresh products from good sources, Super Indo has maintained standard operating procedures in all lines of work. As a supporter of local products, Super Indo is committed to advancing local economy by partnering with local farmers and empowering MSMEs that become suppliers for Super Indo outlets.

Super Indo always creates job opportunities for local communities as it grows and expands its network. Super Indo always promotes a healthy and inclusive work environment that can inspire others in the community to pursue careers with Super Indo.

Super Indo believes that its service is not only about providing the best service and quality products, but also about building positive change for our community and becoming better neighbors. This is reflected in its series of sustainable activities, ranging from promoting a healthy lifestyle, charity activities, and waste-free management.

Running a business there are many factors that entrepreneurs must pay attention to for the success of their business. The location of the company is the key to the efficiency and effectiveness of longterm company sustainability (Haming, Nurnajamuddin, Hafied, \& Serang, 2017).

Product diversity refers to the product's completeness in terms of the depth, breadth, and quality of the products promised, as well as their availability in the store at all times. According to James $\mathrm{F}$. Engels, product completeness (Engel, Blackwell, \& Miniard, 2001refers to the product's depth, breadth, and quality, or even its availability in the shop at any time.

To survive, entrepreneurs must work hard and be able to compete with competitors. In a competitive situation, the location factor can be critical factors and makes it very important (Handoko, 2011).

The formulations of the problems in this study are: a.) does the Choice of place affect business continuity to Superindo? and b.) does product availability affect business continuity to Superindo?

Based on the above problem formulations, the objectives of this study are: a.) to analyze the effect of Choice of place on business continuity to Superindo and b.) to analyze the effect of product availability on business continuity to Superindo.

If the products/services received by consumers are in line with their expectations, the quality of the service will be satisfying ( $P$. Kotler \& Keller, 2009). The perception of the quality of a service depends on how a provider understands the expectations of their consumers towards the products/services provided.

\section{B. LITERATURE REVIEW}

The selection of the location of an organization (company) will affect the riskand the profits of the company overall, the location has a significant impact on both fixed and variable costs, both in the short, medium, and long term.. As for example, transportation costs alone can up to $25 \%$ of the product selling price (depending on the product and type production or services rendered). Thing this means that a quarter of the total company income as possible needed only to cover costs transport of incoming rare metals and products of service that come out of company (Heizer \& Render, 2008).

Location is a place where business activities is or are carried out. Before discussing location theories, it is first needed to know the definition of the location itself. Location is a place where a company does business (Swastha, Basu, 2014).

According to Fandy Tjiptono, "Business location is or where the company conducts activities for producing goods and services concerned with the economy (Tjiptono \& Chandra, 2018).

The choice of business location is one of the business decisions that must be made carefully. Previous studies have found that business location has an effect on the success or success of a business (Wahyudi, 2014). 


\section{песо

According to Kotler (Philip Kotler \& Armstrong, 2018) "One of the keys to success / success is the location, the location starts with selecting the community". This decision is highly dependent on the potential for economic growth and stability, competition, the business climate, and so on.

In selecting consumer stores, there are evaluation criteria including comfort, service, product completeness, and so on, making a very important factor and which must be considered by the manufacturers because it will make a comparison for consumers to choose which stores to be visited. In comparing supermarkets, about which to be visited, consumers will consider completeness of the products, and whether or not the products are sold on self-service. If there is a more complete self-service despite the distance traveled, then the consumers will visit a supermarket with more complete products (Blackwell, Miniard, \& Engel, 2001).

According to Tjiptono (Wibawa, 2012) Products are anything that a manufacturer can provide to the market in order to gain market attention, request, seek, purchase, use, or consumption to meet the needs or desires of the relevant market.

Meanwhile, according to Philip Kotler (Wibawa, 2012) Products are everything which can be offered to the market to satisfy a want or need.

Another Philip Kotler's statement (Ali, Waluyo, \& Listyorini, 2013) The completeness of a product refers to the availability of all types of products offered by a producer for consumers to own, use, or wear...

Product completeness is a procurement activity items that fit the business the store operates (product-based food, clothing, household goods, general products, and others) to be supplied instore at a specified amount, time, and price suitable to achieve the target store or retail company (Ma'ruf, 2005).

According to Utami (Utami, 2012) Product completeness refers to the breadth, depth, and quality of the products available, as well as their accessibility in the store at all times.

According to Raharjani (RAHARJANI, 2005) argues product completeness variable includes the variety of goods sold in the market self-service and the availability of these goods in supermarkets. Indicator of the completeness of the product, namely: 1.) Diversity of products sold, 2.) Variations of products sold, 3.) Availability of products being sold, and 4.) Kinds of brands available.

Another definition of product availability is a factor related to the ease of obtaining the products, as well as everything that customers need in order to consume the products (Conlon \& Mortimer, 2012).

In addition, the durability of goods/products also guarantees the availability of goods/products in stores, so that consumers can buy these goods/products whenever they want. According to Kotler, durable goods are tangible items that can usually last for a long time with a lot of usages (the economic age for their normal use is one more year extention), for example, refrigerators, washing machines, clothes, and others (SE,MM, 2019).

The concept of marketing is a business philosophy which states that the satisfaction of consumer needs is the economic and social conditions for the survival of the company or business continuity (Swastha, Basu, 2014).

According to Ishaq, Bhutta, Hamayun, Danish, \& Hussain, loyal customers use more company products and use these products in a longer period of time. Losing loyal customers can mean losing revenue streams in the future. Loyalty is a process, in which at the end of the process, satisfaction has an effect on perceived quality, which can have an impact on loyalty and intention for certain behaviors of a customer (Andrian, 2020).

Running a business activity clearly requires a place of business known as business location. With the location, consumers can see firsthand goods produced or sold in both type, quantity, and price. Thus, consumers can more easily choose and interact or spend on the products offered directly (Kasmir, 2014). 
The procurement of goods in accordance with shop-run businesses (foodstuffs, clothing, and housewares, general goods, and others or combination) to be provided in the stores at an amount, time, and the right price to reach the stores or target retail companies is referred to as product completeness. Consumers will have a positive impression of a brand if It can provide consumers with goods that they require and want so they can create repeat purchases (Grubor, Milićević, \& Djokic, 2016).

With the association of factors on Choice of place, product availability, and business continuity, the thinking framework in this study is described as follows:

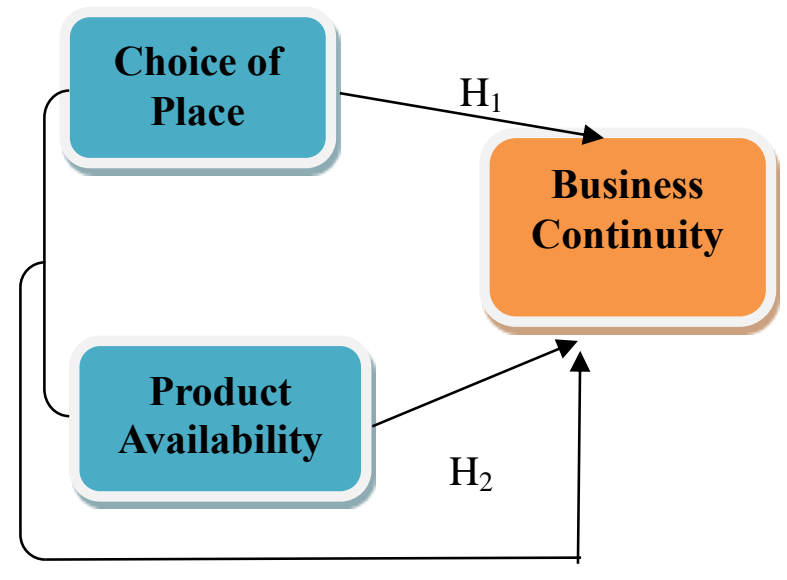

$\mathrm{H}_{3}$

\section{Figure 1. Thinking Framework}

The hypotheses in the study's recommendations are: 1. ) $\mathrm{H}_{1}$ : There is a significant effect of Choice of place on business continuity to PT. Lion Super Indo (Superindo Stores); 2.) $\mathrm{H}_{2}$ : There is a significant effect of product availability on business continuity to PT. Lion Super Indo (Superindo Stores), and 3.) $\mathrm{H}_{3}$ : There is a significant effect of Choice of place and product availability on business continuity to PT. Lion Super Indo (Superindo Stores).

\section{RESEARCH METHOD}

Metode This type of research is quantitative descriptive. A quantitative descriptive research is a type of research in which the data that have been collected are analyzed quantitatively using descriptive or inferential statistics, so it can be concluded whether the formulated hypotheses are proven or not (Sugiyono, 2017). Quantitative research is typically conducted on samples drawn at random, so that research findings can be generalized to the population from which the samples were drawn. The researchers conducted research in order to obtain data and information used as material for analysis. In this case, the types of data needed are: a.) Primary data sourced from consumers in several Superindo stores in Bekasi Timur sub-district by distributing questionnaires, and respondents' answers were measured using Likert's scale measurement scale, and b.) Secondary data sourced from companies in the form of sales data and a general description as well as the company's organizational structure. 


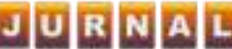

Population is a broad category that includes objects/subjects with specific qualities and characteristics chosen by researchers to be studied and from which conclusions can be drawn. (Sugiyono, 2017). The sample in this study was all consumers in two Superindo stores in Bekasi Timur sub-district during November 2020 as many as 200 customers/respondents by using the Slovin formula.

According to Wiradi (Wiradi et al., 2014) states "quantitative research, such as a quantitative methodology research procedures that produce data in numbers and generally analyzed by using descriptive or inferential statistics."

To get more accurate data, a validity test was first performed to test the validity of each item in question (content validity). A validity measure is a metric that indicates the degree to which an instrument is valid (Arikunto, 2014). A questionnaire is considered valid if the questions on it can reveal something that will be measured by it. Validity test was done with the help of SPSS software program version 22.00. Validity values can be seen in the Corrected Item - Total Correction column. If the correlation number obtained was greater than the critical number $\quad\left(r_{\text {count }}>r_{\text {table }}\right)$, then the instrument was valid.

A reliability test is a tool for determining the reliability of a questionnaire that serves as an indicator of a variable. If a person's answer to a question is consistent, the question item is said to be reliable. If a measuring instrument or research instrument can be used twice to measure the same symptoms with the measurement results obtained relatively consistent, then the measuring instrument or instrument is reliable. To test the reliability or reliability of measuring instruments or instruments in this study, the Cronbach's Alpha coefficient was used. To find out the consistency or confidence of the measurement results that contain the accuracy of the measurement, then the reliability or construct test of a construct is said to be reliable if it gives a Cronbach Alpha $>0.60$.

Normality test aims to test whether in the regression model, confounding or residual variables have a normal distribution or not. For normality use, it can be done by graphical analysis, Specifically, the Normal P-P Plot of Regression Standardized Residual and histogram graphs are used.

Multicollinearity. The purpose of this test is to see if the regression model discovered a relationship between the independent variables (Independent). A good regression model should not produce a relationship between the independent variables. The value of Variance Inflation Factor demonstrates multicollinearity (VIF). If the VIF is 10, there is no multicollinearity between the independent variables in the model.

Scatterplot charts are useful for testing heteroscedasticity. A regression model is under consideration heteroscedastic if the points on the $\mathrm{Y}$ axis spread randomly and do not form a clear pattern, as determined by graph analysis between the dependent's predicted values variable and the independent variables.

The data analysis model used in this study is Multiple Linear Regression test with the following models:

\begin{tabular}{|lll}
\hline$=a+b_{1} X_{1}+b_{2} X_{2}+e$ & & \\
\hline$Y \quad=$ Business Continuity & $a$ & $=$ Constant \\
$X_{1} \quad=$ Choice of Place & $b 1-b 2$ & $=$ Variable Coefficient \\
$X_{2} \quad=$ Product Availability & e & $=$ Error Value
\end{tabular}

The hypothesis $\mathrm{F}$ test demonstrates that all independent or independent variables in the model have a combined influence on the dependent variable. The $F$ test is used to determine the significance of the relationship between the dimensions of the independent variables and the dependent variable. 


\section{.ас

The form of testing is as follows: 1.) $\mathrm{H}_{0}: b_{1}, b_{2}=0$ (Choice of place and Product Availability simultaneously do not have effect on Business Continuity of Superindo Stores in Bekasi Timur SubDistrict), and 2.) $\mathrm{H}_{1}: \mathrm{b}_{1}, \mathrm{~b}_{2} \neq 0$ (Choice of place and Product Availability simultaneously have affect on Business Contiuity of Superindo Stores in Bekasi Timur Sub-District).

The $F$ count will be compared to the $F$ table at a significant level in this study $(\alpha)=5 \%$. The research criteria for the hypothesis in this $F$ test are: 1.) The hypothesis is rejected if $F_{\text {count }}<F_{\text {table }}$, and 2.) The theory has been accepted if $F$ count $>F_{\text {table. }}$

The t-test statistic essentially shows how far one explanatory/independent variable can explain variation in the dependent variable on its own. The T-test was used to determine whether each independent variable had a significant impact on the dependent variable. The form of testing is as follows: 1.) $\mathrm{H}_{0}: \mathrm{b}_{1}, \mathrm{~b}_{2}=0$ (Choice of place and Product Availability do not have partial effect on Business Continuity of Superindo Stores in Bekasi Timur Sub-District), and 2.) $\mathrm{H}_{1}: \mathrm{b}_{1}, \mathrm{~b}_{2} \neq 0$ (Choice of place and Product Availability have partial effect on Business Continuity of Superindo Stores in Bekasi Timur Sub-District). To know whether the proposed hypothesis is accepted or rejected is done by comparing the value of $t_{\text {count }}$ with $t_{\text {table }}$ at a $90 \%$ confidence level. Criteria for research hypothesis in the t-test are: a.) If $t$ count $<t$ table then $H_{0}$ is rejected, and $b$.) If $t$ count $>t$ table then $H_{1}$ is acceptable.

The coefficient of determination measures the model's ability to explain the variation in the dependent variable. The coefficient of determination ranges from 0 to 1 . The small coefficient of determination indicates that The ability of independent data to describe variation the dependent variable's range is extremely constrained. A value near one indicates that the independent variables provide nearly all of the information required to predict the variation of the dependent variable.

\section{RESEARCH RESULTS}

Validity Test : The validity analysis is performed to determine a questionnaire's reliability. To test the validity, the correlation analysis method is used.

Table 1.1. Validity Test

\begin{tabular}{|c|c|c|c|c|c|}
\hline & $\begin{array}{c}\text { Scale Mean if } \\
\text { Item Deleted }\end{array}$ & $\begin{array}{c}\text { Scale } \\
\text { Variance if } \\
\text { Item Deleted }\end{array}$ & $\begin{array}{c}\text { Corrected } \\
\text { Item-Total } \\
\text { Correlation }\end{array}$ & $\begin{array}{c}\text { Squared } \\
\text { Multiple } \\
\text { Correlation }\end{array}$ & $\begin{array}{c}\text { Cronbach's } \\
\text { Alpha if Item } \\
\text { Deleted }\end{array}$ \\
\hline Choice_Of_Place & 43.14 & 6.336 & 0.590 & 0.590 & 0.383 \\
Product_Availability & 42.99 & 6.874 & 0.673 & 0.601 & 0.291 \\
Business_Continuity & 42.54 & 10.019 & 0.215 & 0.057 & 0.864 \\
\hline
\end{tabular}

Table 1.2. Validity Test Results Choice of place, Product Availability, and Business Continuity variables With $n=200, d f=200-2=198$, so $r_{\text {table }}$ is equal to 0.1388

\begin{tabular}{|c|c|c|c|}
\hline VARIABLE & R COUNT & R TABLE & RESULT \\
\hline Choice of place & 0.590 & 0.1388 & Valid \\
\hline Product Availability & 0.673 & 0.1388 & Valid \\
\hline Business Continuity & 0.215 & 0.1388 & Valid \\
\hline
\end{tabular}


Table 1.3. Correlations

\begin{tabular}{|cc|c|c|c|}
\hline & & $\begin{array}{c}\text { Choice_Of_ } \\
\text { Place }\end{array}$ & $\begin{array}{c}\text { Product } \\
\text { Availability }\end{array}$ & $\begin{array}{c}\text { Business } \\
\text { Continuity }\end{array}$ \\
\hline Choice_Of_Place & Pearson Correlation & 1 & $0.768^{* *}$ & $0.171^{*}$ \\
& Sig. (2-tailed) & & 0.000 & 0.015 \\
& $\mathrm{~N}$ & 200 & 200 & 200 \\
\hline Product_Availability & Pearson Correlation & $0.768^{* *}$ & 1 & $0.237^{* *}$ \\
& Sig. (2-tailed) & 0.000 & & 0.001 \\
& $\mathrm{~N}$ & 200 & 200 & 200 \\
\hline Business_Continuity & Pearson Correlation & $0.171^{*}$ & $0.237^{* *}$ & 1 \\
& Sig. (2-tailed) & 0.015 & 0.001 & \\
& $\mathrm{~N}$ & 200 & 200 & 200 \\
\hline
\end{tabular}

Source: Data processed with SPSS

Judged from the outputs, the significance results (Sig. 2-tailed) for all indicators show significant results $(0.000,0.001$ and $0.015<0.05)$, as a result, each question indicator is determined to be valid.

Reliability Test : This test is carried out to find out the consistent results of an answer about the respondents' responses. The table below summarizes the results of the reliability tests for the following criteria: location, product, availability, and business continuity.

Table 1.4.

Reliability Test of Choice of place, Product Availability, and Business Continuity

\begin{tabular}{|c|c|c|}
\hline Cronbach's Alpha & $\begin{array}{c}\text { Cronbach's Alpha Based on } \\
\text { Standardized Items }\end{array}$ & N of Items \\
\hline 0.660 & 0.659 & 3 \\
\hline
\end{tabular}

Source: Data processed with SPSS

Based on Table 1.4 above, The reliability test outcomes are displayed. Because the Cronbach's Alpha value is greater than 0.60 in the table above, it can be concluded that the measuring instrument is reliable. 
Normality Test : The normality test determines whether or not the confounding or residual variables in the regression model have a normal distribution.

Table 2.1. Normality Test

One-Sample Kolmogorov-Smirnov Test

\begin{tabular}{|c|c|c|c|c|}
\hline & & $\begin{array}{c}\text { Choice_Of_ } \\
\text { Place }\end{array}$ & $\begin{array}{l}\text { Product } \\
\text { Availability }\end{array}$ & $\begin{array}{l}\text { Business } \\
\text { Continuity }\end{array}$ \\
\hline \multirow{2}{*}{$\begin{array}{c}\mathrm{N} \\
\text { Normal Parameters }^{\mathrm{a}, \mathrm{b}}\end{array}$} & & 200 & 200 & 200 \\
\hline & Mean & 21,19 & 21.35 & 21.80 \\
\hline & Std. Deviation & 1.794 & 1.571 & 1.629 \\
\hline Most Extreme & Absolute & 0.143 & 0.183 & 0.174 \\
\hline \multirow[t]{2}{*}{ Differences" } & Positive & 0.136 & 0.183 & 0.166 \\
\hline & Negative & -0.143 & -0.177 & -0.174 \\
\hline \multirow{2}{*}{\multicolumn{2}{|c|}{$\begin{array}{c}\text { Test Statistic } \\
\text { Asymp. Sig. (2-tailed) }\end{array}$}} & 0.143 & 0.183 & 0.174 \\
\hline & & $0.000^{c}$ & $0.000^{c}$ & $0.000^{c}$ \\
\hline
\end{tabular}

The Kolmogorov-Smirnov Test statistical test was used to determine whether the data was normally distributed or not. Residuals distribute normal if it has a significance value > 0.05 (Ghozali, 2016).

The variable values Asymptot Significant are shown in the table above (2-tailed) of Choice of place (0.000), Product Availability (0.000), and Business Continuity (0.000) are less than $\alpha=0.05$, so those variables' data are Not Normally Distributed but Having Significant Effect.

Multicolinierity Test : The Multicollinearity Test determines whether the regression model discovered a correlation between independent variables (Independent). According to Sunyoto (Sunyoto, 2016) explaining the test multicollinearity was applied to multiple regression analysis consisting of two or more independent variables or independent variables $(X 1,2,3, \ldots, n)$ where the closeness of the relationship between the independent variables will be measured through the quantity correlation coefficient ( $r$ ). A linear regression model should produce no relationship between the independent variables. The value of the Variance Inflation Factor demonstrates multicollinearity (VIF). If the VIF is greater than 10, The absence of multicollinearity between in this study's regression model, the independent variables allows to conclude that there is no multicollinearity.

Table 2.2. Multicolinierity Test

\begin{tabular}{|c|c|c|c|c|c|c|c|c|}
\hline \multirow{2}{*}{\multicolumn{2}{|c|}{ Model" }} & \multicolumn{2}{|c|}{$\begin{array}{l}\text { Unstandardized } \\
\text { Coefficients }\end{array}$} & \multirow{2}{*}{$\begin{array}{c}\text { Standardized } \\
\text { Coefficients" } \\
\text { Beta }\end{array}$} & \multirow[b]{2}{*}{$\mathrm{t}$} & \multirow[b]{2}{*}{ Sig. } & \multicolumn{2}{|c|}{$\begin{array}{l}\text { Collinearity } \\
\text { Statistics }\end{array}$} \\
\hline & & $\mathrm{B}$ & Std. Error & & & & Tolerance & VIF \\
\hline \multirow[t]{3}{*}{1} & (Constant) & 16.610 & 1.555 & & 10.685 & 0.000 & & \\
\hline & Choice_Of_Place & -0.024 & 0.098 & -0.027 & -0.247 & 0.805 & 0.410 & 2.438 \\
\hline & Product_Availability & 0.267 & 0.112 & 0.258 & 2.385 & 0.018 & 0.410 & 2.438 \\
\hline
\end{tabular}

Source: Data processed with SPSS 


\section{Tण

Taking a look at the analysis results in the table above, it is shown that there are no independent variables that have Variance Inflation Factor (VIF) > 10 and also there are no independent variables that have Tolerance value $<0.10$. Therefore, it can be concluded that there is No Multicollinearity between the independent variables in the regression model.

Heteroscedasticity : Scatterplot charts can be used to test heteroscedasticity. If the points spread randomly and do not form a clear pattern that spreads above or below zero on the $Y$ axis, the regression model is said to have no Heteroscedasticity.

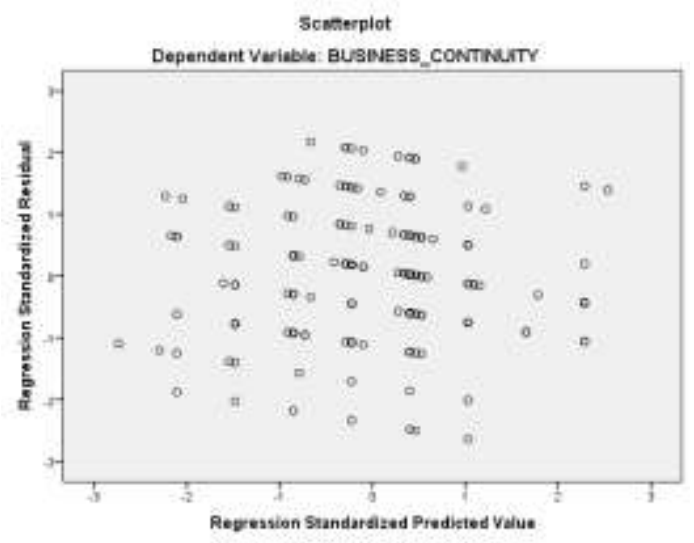

Figure 2. Heteroscedasticity Test

Source: Data processed with SPSS

To determine the presence or absence of heteroscedasticity symptoms, a graph of heteroscedasticity between the predicted values of the dependent variable and the independent variable can be used. From this scatterplot. The points are randomly distributed and spread both above and below the number 0 and the $Y$ axis, as seen. It can be concluded that there is no heteroscedasticity in the regression model, implying that the regression model is suitable for testing..

Multiple Linier Regression Analysis : According to Umi Narimawati (Sarwono \& Narimawati, 2020) Multiple linear regression analysis is defined as: "An association analysis that is used simultaneously to examine the effect of two or more independent variables on one dependent variable with an interval scale". The equation for multiple linear regression analysis is shown below: 
Table 3. Test of Multiple Linear Regression Coefficients $^{\mathrm{a}}$

\begin{tabular}{|cc|c|c|c|c|c|}
\hline \multirow{2}{*}{ Model } & \multicolumn{2}{|c|}{$\begin{array}{c}\text { Unstandardized } \\
\text { Coefficients }\end{array}$} & $\begin{array}{c}\text { Standardized } \\
\text { Coefficients }\end{array}$ & & \\
\cline { 3 - 5 } & B & Std. Error & Beta & $\mathrm{t}$ & Sig. \\
\hline 1 & (Constant) & 16.610 & 1.555 & & 10.685 & 0.000 \\
& Choice_Of_Place & -0.024 & 0.098 & -0.027 & -0.247 & 0.805 \\
& Product_Availability & 0.267 & 0.112 & 0.258 & 2.385 & 0.018 \\
\hline
\end{tabular}

Source: Data processed with SPSS

\section{Business Continuity $=16.610-0.024$ Choice of Place +0.267 Product Availability + eror}

The estimated regression model can be deduced as described below :

a. A constant of 16.610 states that Business Continuity is 16.610 if the variables Choice of Place and Product Availability are considered constant or equal to zero.

b. The Choice of place regression coefficient is - 0.024 , which means that if the value of Choice of place does not increase (0), then Business Continuity will decrease by 0.024.

c. Product Availability variable regression coefficient is 0.267 , which means that if the value of Product Availabiliity increases by one unit, then Business Continuity will increase by 0.267 .

Simultaneous $\mathbf{F}$ Test : This research looked at, the $F$ test is used to evaluate the level of significance of the two topics of Choice of place and Product Availability variables on Business Continuity variable. The $\mathrm{F}$ test is carried out to see the influence of the independent variables (free) together has an effect on dependent variable (Ferdinand, 2016).

Table 4.1. Simultaneous Hypothesis Test (F test)

Anova $^{a}$

\begin{tabular}{|cc|c|c|c|c|c|}
\hline & Sum of & df & “Mean Square & $\mathrm{F}$ & Sig. \\
\hline 1 & Regression & 29.863 & 2 & 14.931 & 5.905 & $0.003^{\mathrm{b}}$ \\
& Residual & 498.137 & 197 & 2.529 & & \\
Total & 528.000 & 199 & & & \\
\hline
\end{tabular}

Source: Data processed with SPSS

The value is demonstrated by statistical calculations of $F_{\text {count }}=5.905>F_{\text {table }}=3.04$ and a significant value of $0.003<0.05$, which shows that Choice of Place and Product Availability variables Significantly Influenced Business Continuity. 
ISSN (print) : 2598-9545 \& ISSN (online) : 2599-171X

Partial $\mathbf{t}$ Test : The t-test can be used to test the regression model's significance for each variable separately. as shown in the table below:

Table 4.2. Partial Hypothesis Test (t-test)

Coefficients $^{\mathrm{a}}$

\begin{tabular}{|c|c|c|c|c|c|}
\hline \multirow{2}{*}{ Model } & \multicolumn{2}{|c|}{$\begin{array}{c}\text { Unstandardized } \\
\text { Coefficients }\end{array}$} & $\begin{array}{c}\text { Standardized } \\
\text { Coefficients }\end{array}$ & & \\
\cline { 2 - 4 } & $\mathrm{B}$ & Std. Error & Beta & $\mathrm{t}$ & Sig. \\
\hline 1 (Constant) & 16.610 & 1.555 & & 10.685 & 0.000 \\
Choice_Of_Place & -0.024 & 0.098 & -0.027 & -0.247 & 0.805 \\
Product_Availability & 0.267 & 0.112 & 0.258 & 2.385 & 0.018 \\
\hline
\end{tabular}

Source: Data processed with SPSS

a. The preliminary the outcome of the hypothesis for the selection of the place variable show the worth of $t_{\text {count }}=-0.247<t_{\text {table }}=1.97$ with a value of significance of $0.805>0.05$, which can be concluded that the Choice of place variable has a Negative and Not Significant Effect on Business Continuity.

b. Hypothesis test partial results for Product Availability variable indicate the value of $t_{\text {count }}=2.385>t_{\text {table }}=1.97$ with a value of significance of $0.018<0.05$, which can be concluded that the Product Availability variable has a Positive and Significant Effect on Business Continuity.

Coefficient Determination Test $\left(r^{2}\right)$ : This granger causality test is used to evaluate the concentration of influence the independent variables have. have on the dependent variable. It is determined what the coefficient of determination by the adjusted $r$-squared $\left(r^{2}\right)$ value.

Table 5. Determination Coefficient Test $\left(r^{2}\right)$ Model Summary

\begin{tabular}{|c|c|c|c|c|}
\hline Model & $r$ & $r$ Square & $\begin{array}{c}\text { Adjusted } r \\
\text { Square }\end{array}$ & $\begin{array}{c}\text { Std. Error of the } \\
\text { Estimate }\end{array}$ \\
\hline 1 & $0.238^{\mathrm{a}}$ & 0.057 & 0.047 & 1.590 \\
\hline
\end{tabular}

Source: SPSS was used process the data 


\section{E. CONCLUSION}

Based on the results of the research, it can be drawn research conclusions as follows: 1.) Choice of place Variable has a negative and no significant effect on Business Continuity, and 2.) Product Availability Variable has a positive and significant effect on Business Continuity.

Based on the results of the study, it is showed that Product Availability variables was only able to effect on Business Continuity by $4.7 \%$, and the next researchers should add other factors that are not examined in this study such as price, product quality, promotion or other kind of variables.

\section{REFERENCES}

Ali, M., Waluyo, H., \& Listyorini, S. (2013). Pengaruh Keragaman Menu, Kualitas Produk, Citra Merek, Dan Iklan Terhadap Keputusan Pemebelian. Jurnal IImu Administrasi Bisnis S1 Undip.

Andrian, W. W. (2020). The Impact of Online Shopping Services and Satisfacion Levels to Customer's Loyalty. American Journal of Humanities and Social Sciences Research (AJHSSR).

Arikunto, S. (2014). Prosedur Penelitian: Suatu Pendekatan Penelitian. Rineka Cipta.

Berman, B., and Evans, J. . (2010). Retail Managemnet. Prentice Hall, New Jersey.

Blackwell, R. D., Miniard, P. W., \& Engel, J. F. (2001). Consumer behavior, 9th Eds. New Youk: Harcourt.

Conlon, C. T., \& Mortimer, J. H. (2012). Effects of Product Availability: Experimental Evidence. SSRN Electronic Journal. https://doi.org/10.2139/ssrn.1705371

Engel, J. F., Blackwell, R. D., \& Miniard, P. W. (2001). Perilaku Konsumen, Jilid 2. Jakarta: Binarupa Aksara.

Ferdinand, P. D. A. (2016). Metode Penelitian Manajemen: Pedoman Penelitian untuk Skripsi, Tesis dan Disertasi IImu Manajemen. BP Undip 2.

Ghozali, I. (2016). Aplikasi Analisis Multivariate dengan Program IBM SPSS 23.

Grubor, A., Milićević, N., \& Djokic, N. (2016). The effect of inventory level on product availability and sale. Prague Economic Papers. https://doi.org/10.18267/j.pep.556

Haming, P., Nurnajamuddin, M., Hafied, H., \& Serang, S. (2017). Effect of Work Attitude and Total Productive Maintenance on the Overall Equipment Effectiveness and Production Continuity. IRA-International Journal of Management \& Social Sciences (ISSN 2455-2267). https://doi.org/10.21013/jmss.v7.n3.p3

Handoko, T. H. (2011). Manajemen Personalia dan Sumber Daya Manusia. Pengantar Manajemen.

Heizer \& Render. (2008). Manajemen Operasi Jasa. Manajemen Operasi.

Kasmir. (2014). Kewirausahaan Edisi Revisi. In Kewirausahaan edisi revisi.

Kotler, P., \& Keller, K. L. (2009). Marketing management (13th ed.). In Prentice Hall.

Kotler, Philip. (2012). Kotler P. Marketing management/Philip Kotler, Kevin Lane Keller. Pearson Educ Int. 2012. Pearson Education International.

Kotler, Philip, \& Armstrong, G. (2018). Kotler \&amp; Armstrong, Principles of Marketing | Pearson. Pearson. 
Lesmana, R., Widodo, A. S., \& Sunardi, N. (2020). The Formation of Customer Loyalty From Brand Awareness and Perceived Quality through Brand Equity of Xiaomi Smartphone Users in South Tangerang. Jurnal Pemasaran Kompetitif, 4(1), 1-12.

Ma'ruf, H. (2005). Pemasaran Ritel.Jakarta: Gramedia Pustaka Utama. In Pemasaran ritel.

RAHARJANI, J. (2005). ANALISIS FAKTOR - FAKTOR YANG MEMPENGARUHI KEPUTUSAN PEMILIHAN PASAR SWALAYAN SEBAGAI TEMPAT BERBELANJA (Studi Kasus Pada Pasar Swalayan Di Kawasan Seputar Simpang Lima Semarang ). Jurnal Studi Manajemen Dan Organisasi (JSMO).

Sarwono, J., \& Narimawati, U. (2020). Membuat Skripsi, Tesis, dan Disertasi dengan Partial Least Square SEM (PLS-SEM). CV ANDI OFFSET (Penerbit Andi).

SE,MM, A. (2019). Digital Marketing dan Ragam Produk pada Minat Beli Konsumen Toko Online Shopee (Studi Kasus pada Mahasiswa Prodi Manajemen Fakultas Ekonomi Universitas Bhayangkara Jakarta Raya Angkatan 2016). Ekspektra: Jurnal Bisnis Dan Manajemen. https://doi.org/10.25139/ekt.v3i1.1430

Sunardi, N., \& Lesmana, R. (2020). Konsep Icepower (Wiramadu) sebagai Solusi Wirausaha menuju Desa Sejahtra Mandiri (DMS) pada Masa Pandemi Covid19. JIMF (Jurnal IImiah Manajemen Forkamma), 4(1).

Nardi Sunardi Et Al (2020). Determinants of Debt Policy and Company's Performance, International Journal of Economics and Business Administration Volume VIII Issue 4, 204-213

Sugiyono. (2017). Metode Penelitian Bisnis (Pendekatan Kuantitatif, Kualitatif, Kombinasi dan R\&DSugiyono. (2017). Metode Penelitian Bisnis (Pendekatan Kuantitatif, Kualitatif, Kombinasi dan R\&D). In Metodelogi Penelitian.). In Metodelogi Penelitian.

Sunyoto, D. 2016. (2016). Metodologi Penelitian Akuntansi. Bandung: PT Refika Aditama. Metodologi Penelitian Akuntansi. Bandung: PT Refika Aditama.

Swastha, Basu, I. (2014). Manajemen Pemasaran Modern. Liberty, Yogyakarta. https://doi.org/10.1017/CBO9781107415324.004

Tjiptono, F., \& Chandra, G. (2018). Manajemen Kualitas Jasa. Yogyakarta. ANDI.

Utami, C. W. (2012). Manajemen Ritel Strategi Dan Implementasi Ritel Modern. Jakarta: Salemba Empat.

Wahyudi, N. (2014). Analisis Faktor-Faktor Pemilihan Lokasi Usaha Terhadap Kesuksesan Usaha Jasa Mikro Di Kecamatan Sungai Kunjang. Ekonomia.

Weitz, L. (2019). Retailing Management 10th edition. McGraw-Hill/Irwin.

Wibawa, i made dangsina. (2012). Analisis Pengaruh Promosi, Kelengkapan Produk, Kualitas Pelayanan, Kenyamanan Berbelanja Terhadap Keputusan Pembelian Pada Waserba Tenera Asahan. Semarang , Universitas Diponogoro.

Wiradi, G., Vollenhoven, C. Van, Sofia, A., Soehadha, M., Silaen, S. dan W., Scott, J., ... Ritzer, G. (2014). Metodologi Penelitian Sosial untuk Penulisan Skripsi dan Tesis. Jurnal Pemikiran Sosiologi. 